European journal of American studies

\title{
Introduction : Storying the West in Postfrontier Literature
}

David Rio and Øyunn Hestetun

\section{(2) OpenEdition \\ Journals}

Electronic version

URL: https://journals.openedition.org/ejas/9249

DOI: $10.4000 /$ ejas. 9249

ISSN: 1991-9336

Publisher

European Association for American Studies

\section{Electronic reference}

David Rio and Øyunn Hestetun, "Introduction : Storying the West in Postfrontier Literature", European journal of American studies [Online], 6-3 | 2011, document 1, Online since 22 September 2011

connection on 08 July 2021. URL: http://journals.openedition.org/ejas/9249 ; DOI: https://doi.org/

10.4000/ejas.9249

This text was automatically generated on 8 July 2021.

Creative Commons License 


\title{
Introduction : Storying the West in Postfrontier Literature
}

\author{
David Rio and Øyunn Hestetun
}

No place is a place until things that have happened in it are remembered in history, ballads, yarns, legends, or monuments. Wallace Stegner, "The Sense of Place"

1 The contributions to this special issue of the European Journal of American Studies (EJAS) examine the different ways in which literary interpreters of the American West, in particular since the 1960s, have contributed to a broadening of our conception of the region. The current interest in the region is evidenced not only in western literature, but also in literary, social, cultural, and historical studies, thus exemplifying Charles L. Crow's claim that, "it is difficult to understand the large issues of American culture and literature [...] without understanding the literature of regions" (2). More recent western literature and scholarship tend to be heavily marked by revisionist understandings of the historical, cultural, and social history of the region. Accordingly, the region is both portrayed and examined as a diverse entity, consisting of a wide variety of sub-regions, territories, and cultures, while the powerful role still played by the mythology and romance of the old West is recognized.

2 If we look back at how the region and its literary output have been conceptualized over the past few decades, it is worth noticing that A Literary History of the American West from 1987, one of the seminal works that have contributed to the reinvigoration of western literary studies, already acknowledged the problematic implications of the term "western" and stressed the plural dimension of the American West, offering a division of its contents according to different criteria, such as chronology, ethnicity, and geography. For example, its central part was divided into four main sub-regions, each containing different sections. In James H. Maguire's words, "Each sub-region has its own distinctive landscape and history, and a glance at titles of representative western literary studies shows that each sub-region has developed its own body of literature" (323). Updating the Literary West, which appeared in 1997 as a sequel to A Literary History of the American West, maintained the 
division into sub-regions of its predecessor, except that California, formerly included under the heading of "The Far West," now appeared as a separate section. Besides, each sub-region was internally organized according to a variety of criteria, such as states, individual writers, and genres. In general, this volume reflects the new prominence of the issues of race, ethnicity, and gender in western literary studies, and a larger presence of environmental writing in and of the West. It also challenges traditional prejudice against western literature by devoting a lengthy section to an examination of popular western writing, defined by Max Westbrook in the preface to the volume as "another revealing part of the American experience" (xiv). The ambition to stake out new directions for scholarship on the American West also informs the Postwestern Horizons series, launched by The University of Nebraska Press in 2003. The title of the first volume in the seriesNathaniel Lewis's Unsettling the Literary West: Authenticity and Authorship (2003)-is symptomatic of the continued desire to reexamine the literature of the West from a perspective informed by recent theorizing.

3 The present issue of the EJAS represents yet another effort to enrich our understanding of contemporary western writing. Sometimes referred to as postfrontier literature, the more recent literary output of the region tends to engage in a reinterpretation of the region, calling into question the ways in which it has been defined in the past. Thus literature has in fact contributed to a great extent to the development of an alternative to the frontier mentality, a mentality defined by Thomas J. Lyon as "dualistic and casually exploitative in its attitude towards nature, invidiously hierarchical in its approach toward women and minorities, and above all, un-self-critical" (963). The various contributions to this issue bring into focus how postfrontier literature not only has abandoned archetypal male-biased imagery and ethnocentric prejudices associated with the Old American West, but also often addresses the problematic legacy of western myths. Shifting the focus onto the pluralistic condition of this territory, more recent regional literature serves to foreground the fundamentally hybrid interaction of cultures and languages characteristic of the shifting borderland condition of the American West. As Robert F. Gish has claimed, "West is `here and now' from indigenous perspectives. West is perhaps still west, although maybe urban and rural, from Anglo and African American perspectives. West, however, is east from Asian American perspectives. West is north from Mexican American perspectives" (38). Some of the contributions also illustrate how the inclusion of texts dealing with urban space represents a notable change in the conception of the West and western writing.

The reorientation of western writing in the last five decades could be said to be related to a series of broader social and cultural trends and developments. Among these are the expansion of the New Western History, the growth of environmental awareness, the increasing recognition of ethnic and cultural diversity, the consolidation of feminist studies, the shift from grand narratives to "micro-narratives," and the attention given to space and place in recent scholarship. A common denominator of this fiction is its emphasis on the actual experience of living or staying in the West rather than on the classical image of going West. As Russell Martin notes in his introduction to New Writers of the Purple Sage: An Anthology of Contemporary Western Writing, "it appears that the region's writers are paying rather more attention to the issue of home, at once simple and enormously complex, to the questions of why and how we stay anchored here despite that sweep of change" (xix). Besides, an important number of recent writers tend to focus on the western community, on the interdependence of its different members, rather than on individual efforts or circumstances. Thus they illustrate 
Doreen Massey's argument in Space, Place and Gender, that places "are not so much bounded areas as open and porous networks of social relations," which also means that, "what is to be the dominant image of any place will be a matter of contestation and will change over time" (121). The maturation of western fiction is also marked by its increasing complexity of characterization, with a particular emphasis on the figure of the anti-hero, and a greater propensity to engage in formal innovation and experimentation.

5 It could be argued that in the past fifty years or so, we have seen the emergence of a literature that reveals a more "real West," while showing increased awareness of the constructed nature of narrative representation. Western writing bears evidence to Wallace Stegner's dictum that, "No place is a place until things that have happened in it are remembered in history, ballads, yarns, legends, or monuments" ("The Sense of Place" 202). In fact, it is possible to talk about a flowering or a renaissance of western writing, if one considers the international recognition of authors such as Cormac McCarthy, James Welch, Barbara Kingsolver, Wallace Stegner, Leslie Marmon Silko, Amy Tan, Larry McMurtry, Raymond Carver, Joan Didion, Louise Erdrich, Rudolfo Anaya, Denise Chavez, Gary Snyder, N. Scott Momaday, Maxine Hong Kingston, Annie Proulx, and Sherman Alexie, to name just a few of the best-known writers.

6 Taken together, the articles in this issue examine not only the mythic and popular dimension of the West, but also neglected or overlooked stories about this region and its writers. The different contributions engage a variety of the critical issues addressed in contemporary literary studies of this territory: the West as an exceptional region as opposed to the West as an inherent part of American culture, the West as bounded place (stasis) versus the West as multi-layered and shifting place (process), the impact of urbanization and technology, the abiding influence of the cultural myths of the old West and the western, spatial organization in the West from the perspective of postmodern geography, or the interaction between identity and landscape. As Jeremy Wells has remarked, "region, with its insistence upon the importance of locality to reconfigure the geographies of literary study, may have become the central complicating concept of the current decade" (203). The various contributions exemplify how "region" and "place" can be employed as useful analytical categories to explore western writing, and to address theoretical and practical aspects of the West as a pluralistic literary space. Among writers discussed are authors such as Joan Didion, Cormac McCarthy, Marilynne Robinson, Mary Clearman Blew, D. J. Waldie, Wallace Stegner, and William S. Burroughs. These writers both illustrate the increasing diversity of western writing (a genre often identified almost exclusively with "formula westerns") and epitomize the vitality of contemporary literature of the American West. ${ }^{1}$

\section{BIBLIOGRAPHY}

Crow, Charles L. Introduction. A Companion to the Regional Literatures of America. Ed. Charles L.

Crow. Malden, MA: Blackwell, 2003. 1-4.

European journal of American studies, 6-3 | 2011 
Gish, Robert F. “Reperceiving Ethnicity in Western American Literature." Lyon et al., Updating 3543.

Lewis Nathaniel. Unsettling the Literary West: Authenticity and Authorship. Lincoln: U of Nebraska P, 2003.

Lyon, Thomas J. Epilogue. Lyon et al., Updating 961-63.

Lyon, Thomas J. et al., eds. Updating the Literary West. Fort Worth: Texas Christian UP, 1997.

Maguire, James H. Introduction. “Part Two: Settled In: Many Wests.” Tayor et al., A Literary History 319-25.

Martin, Russell. Introduction. New Writers of the Purple Sage: An Anthology of Contemporary Western Writing. Ed. Russell Martin. New York: Penguin, 1992. viii-xx.

Massey, Doreen. Space, Place and Gender. Cambridge: Polity, 1994.

Stegner, Wallace. "The Sense of Place." Where the Bluebird Sings to the Lemonade Springs: Living and Writing in the West. New York: Random House, 1992. 199-206.

Taylor, J. Golden, et al., eds. A Literary History of the American West. Fort Worth: Texas Christian UP, 1987.

Wells, Jeremy. "The Arrival of Regions: The Blackwell Companion to theRegional Literatures of America." Review Essay. Western American Literature 41.2 (2006): 202-11.

Westbrook, Max. Preface. Lyon et al., Updating xxiii-xiv.

\section{NOTES}

1. The research for this article was carried out within the framework of the research project FFI2008-03833, funded by the Spanish Ministry of Education.

\section{AUTHORS}

\section{DAVID RIO}

University of the Basque Country, Spain

\section{ØYUNN HESTETUN}

University of Bergen, Norway 